Winter 2009

\title{
Representativity, Civil Society, and the EU Social Dialogue: Lessons from the International Labor Organization
}

\author{
Faina Milman-Sivan \\ University of Haifa, Israel
}

Follow this and additional works at: https://www.repository.law.indiana.edu/ijgls

Part of the Civil Law Commons, European Law Commons, International Law Commons, Labor and Employment Law Commons, and the Law and Politics Commons

\section{Recommended Citation}

Milman-Sivan, Faina (2009) "Representativity, Civil Society, and the EU Social Dialogue: Lessons from the International Labor Organization," Indiana Journal of Global Legal Studies: Vol. 16 : Iss. 1 , Article 12.

Available at: https://www.repository.law.indiana.edu/ijgls/vol16/iss1/12

This Symposium is brought to you for free and open access by the Law School Journals at Digital Repository @ Maurer Law. It has been accepted for inclusion in Indiana Journal of Global Legal Studies by an authorized editor of Digital Repository @ Maurer Law. For more information, please contact rvaughan@indiana.edu.

\section{$\Psi$}

JEROME HALL LAW LIBRARY

INDIANA UNIVERSITY

Maurer School of Law
Blooming ton 


\title{
Representativity, Civil Society, and the EU Social Dialogue: Lessons from the International Labor Organization
}

\author{
Faina Milman-Sivan*
}

\begin{abstract}
This article addresses representativity questions that arise from the formal insertion of private, functional groups within the European Union (EU) governance via the EU social dialogue. It depicts the representativity debate at the $E U$ social dialogue and suggests that important lessons can be learned through the examination of another institutional context in which similar questions have been raised and addressed: the International Labor Organization (ILO) tripartite structure. In addition, it ascertains that the issue of representativity of the EU social partners would further benefit from viewing it in the broader context of the EU "democratic deficit." The article concludes that such an analysis underscores the need to rethink the current understanding of representativity in the EU social dialogue. In particular, it considers the benefits and disadvantages of expanding the notion of representativity to encompass the internal structural mechanisms of the EU social partners.
\end{abstract}

\section{INTRODUCTION}

The two "most important rule-makers in social policy beyond the nation state," the European Union (EU or the Union) and the International Labor Organization

* Assistant Professor at the University of Haifa, Israel. For their helpful comments on an earlier draft, I would like to thank Hanna Lerner and Orna Rbinovich Einy. I would also like to thank the participants of the Indiana Journal of Global Legal Studies Symposium on Operationalizing Global Governance for their questions and comments. An earlier version of this paper was presented at the 2008 Annual Meeting of the Law and Society Association and I am grateful to Kevin Kolben, Brian Langille, Guy Mundluk, and the other participants for their questions and comments. Last, the staff of the Indiana Journal of Global Legal Studies provided useful comments and suggestions, and Roee Tamari and Ido Gleitman provided valuable research assistance.

Indiana Journal of Global Legal Studies Vol. $16 \# 1$ (Winter 2009)

CIndiana University Maurer School of Law — Bloomington 
(ILO), are struggling as the legitimacy of their governance structures is being challenged. In part, these challenges stem from the fact that these leading transnational organizations experiment with the formal incorporation of functional groups (management and employee organizations) in their law-generating processes.

The EU has provided formal legislative authority to EU social partners only since 1992, whereas the ILO has had almost ninety years of experience with formal participation of functional groups. Although academic literature has recently taken an interest in the ILO as a model for engagement with civil society, ${ }^{2}$ in general the ILO's broad experience in addressing questions pertaining to the formal incorporation of functional groups has been historically overlooked. Recently, more researchers have begun to compare the EU and the ILO. ${ }^{3}$ Following this vein, this article explores the ways in which the ILO experience may illuminate the EU's own struggle with issues related to the representativity of its social partners.

The introduction of Articles 138-139 of the European Community Treaty (the Treaty), which served to establish EU social dialogue, gave rise to several debates, among them the question of the representativity of the social partners. ${ }^{4}$ Yet, despite the considerable legislative authority granted to the social partners in the EU social dialogue, nowhere does the Treaty clearly define the term "social partner" or set out any criteria for identifying the groups that should be included in this process. ${ }^{5}$ In a well-known case from 1996, the European Court of First In-

1. Miriam Hartlapp, On Enforcement, Management and Persuasion: Different Logics of Implementation Policy in the EU and the ILO, 45 J. COMMON MKT. STud. 653, 654 (2007).

2. For exceptions, see, e.g., Steve Charnovitz, Two Centuries of Participation: NGOs and International Governance, $18 \mathrm{MICH}$. J. INT'L L. 183, 286 (1997) ("[T] he thesis of this article is that useful lessons can be learned from the practices of the early public international unions, the ILO, and the League of Nations."); Faina Milman-Sivan, The Virtuous Cycle: A New Paradigm for Democratizing Global Governance Through Deliberation, 30 COMP. LAB. L. \& POL'Y J. (forthcoming 2008).

3. See Hartlapp, supra note 1, at 654; Tonya Novitz \& Phil Sypris, Assessing Legitimate Structures for the Making of Transnational Labour Law: The Durability of Corporatism, 35 Indus. L.J. 367, 393-94 (2006). One argument against such comparison is that the EU's governance structure, and, in particular, the EU social dialogue is sui generis. See generally Hartlapp, supra note 1; Novitz \& Sypris, supra, at 367.

4. Articles 3 and 4 of the Treaty Establishing the European Community, Dec. 24, 2002, 2002 O.J. (C 325) 138-138 [hereinafter EC Treaty] were renumbered Articles 138 and 139. This new numbering will be used in this article.

5. One should distinguish between the social partners that are consulted at the "consultative stage," with respect to which the European Commission has set out some criteria for participation, and the "law-generation stage," with respect to which the question of representation remains open, although it was legally challenged in the UAEPME case. Case T-135/96, Union Europeenne de l'A rtisanat et des Petites et Moyennes Enterprises [UEAPME] v. EU Council \& EC Commission, 1998 E.C.R. II-2335 thereinafter UEAPME]. Regarding the consultative stage, the Commission set 
stance (CFI) addressed the legal aspects of this ambiguity. Its decision, however, did not resolve the intricate problem of representativity. ${ }^{6}$

The urgency and complexity of the need to adequately identify EU social partners with the power to create European social law are further intensified when the issue is considered in the broader context of civil society participation in the EU and the effect that such participation might have on the "democratic defi-

out criteria on adapting and promoting the social dialogue at community level. These criteria include (1) being a cross-industry entity; or (2) relating to specific sectors or categories; and (3) being organized at a European level; consisting of organizations, which are themselves an integral and recognized part of member-state social partner structures; and having adequate structures to ensure their effective participation in the consultation process. To date, there are more than fifty organizations that conform to these criteria. See Communication Concerning Application of the Agreement on Social Policy, at 2, COM (1993) 600 final (Dec. 14, 1993). In the 1996 Communication on Social Policy, the Commission specified different criteria providing that it should examine whether the organizations involved have a genuine interest in the matter and can demonstrate significant representation in the domain concerned. See Commission Communication Concerning the Development of the Social Dialogue at Community Level, at 12, COM (1996) 448 final (Sept. 18, 1996). In the 1998 communication, the Commission states that the organizations involved should be sufficiently representative with respect to the scope of the agreement. See Communication from the Commission Adapting and Promoting the Social Dialogue at Community Level, at 10, COM (1998) 322 final (May 20,1998). Note that a more thorough debate on representativitiy is unavoidable, as recognized by the Alain Supiot report, The Transformation of Work and the Future of Labour Law in Europe: A Multidisciplinary Perspective, 138 INT'L LAB. Rev. 31 (1999) [hereinafter Supiot Report]; Commission of the EU Transformation of Labour and Future of Labour Law in Europe, II 467, DG V/98/776 ("In so far as the social partners are involved in the discussion or negotiation of lawfully enforceable provisions, the representativeness is a question of general interest and one which public authorities cannot ignore."). Also note that the European Parliament (EP), the European Economic and Social Committee (ESC), and the three intersectoral organizations, European Union Trade Confederation, Union of Industrial and Employers' Confederations of Europe, and European Centre of Enterprises with Public Participation, have also formulated representativity criteria. These include the criterion that the organizations must be organized at the European level. They must also consist of national affiliates, which are regarded as representatives in their own Member States. Another criterion is that the membership of these organizations must be voluntary. Still another suggested criterion is that the national affiliates are "firmly rooted in the Member States." Looking at the internal democratic decision-making procedures, the organizations should be mandated by their national affiliates to conclude European agreements on their behalf. These European organizations must also have adequate structures to effectively participate in the European social dialogue process. Finally, membership of the European organization should be spread as equally as possible with members in at least three-quarters of the EU Member States. There is no agreement, to date, on any list of criteria. For a more detailed account, see Edith J. A. Franseen, Legal Aspects of the European Social Dialogue 88-9l (2002).

6. Case T-135/96, UEAPME, 1998 E.C.R. II-2335. 
cit" recognized by the EU. The participation of functional interests in EU social dialogue may be justified from a democratic perspective on the grounds that it would be a truly inclusive-and consequently, democratic-process of social norm generation. However, this justification also assumes that these groups ensure their constituents adequate representativity. ${ }^{8}$ The democratic concerns regarding the EU civil society's representativity and its accountability are reflected in the representativity debate elicited by the social partners. ${ }^{9}$ Reviewing this debate in light of the ILO's experience can provide the EU with meaningful insights. In particular, two key themes emerge.

The first theme relates to democratic internal decision-making mechanisms and other internal structures of civil society groups and considers the extent to which such practices constitute a significant factor in determining these groups' representativity. The ILO's recent reforms exemplify that the groups' internal functioning may be used as a representativity criterion, determining who gets a seat at the table. Thus, groups with insufficient internal functioning mechanisms may be excluded from deliberations. The second theme follows directly from the first. If the internal structures that guide the operation of civil society groups are used as a representativity criterion, this may endanger the regulatory autonomy of those groups. An analysis of the ILO's approach toward representativity suggests that the freedom of association norm may be a useful source in the search for legitimate criteria that can strike a balance between the need to maintain regulatory autonomy and the need to ensure groups' democratic internal functioning.

Part I briefly depicts the EU social dialogue and the representativity difficulty it poses. This difficulty will be considered in the broader context of the EU's "democratic deficit." Part II reviews the manner in which the ILO has tackled similar representativity dilemmas and focuses on surveying the recent legal devel-

7. Most scholars today agree that the EU suffers from some kind of democratic deficit. See infra notes 33-34 and accompanying text.

8. Daniela Obradovic, for example, clearly articulates the linkage between EU democracy and accountability, representativity being one component of the latter, stating that "accountability of the European corporatist groups is every bit as essential to a democracy as political accountability, and in large measure, accountability of the social partners is part of the larger framework of political accountability in the Union." Daniela Obradovic, Accountability of Interest Groups in the Union Lawmaking Process, in Lawmaking IN THE European Union 354, 357 (Paul Craig \& Carol Harlow eds., 1998).

9. The term "civil society" is broad enough to include workers' and employers' organizations. For a survey of the term civil society, see, for example, Ronnie D. Lipschutz, Reconstructing World Politics: The Emergence of Global Civil Society, MiLlennium, Dec. 1992, at 389, 396-99; Martin Shaw, Civil Society and Global Politics: Beyond a Social Movements Approach, Millennium, Dec. 1994 , at $647,648-50$ (1994). 
opments therein. Lastly, Part III draws on these observations and concludes with an analysis of the ways in which the lessons of the ILO experience can be applied to the EU context.

\section{EU Social Dialogue and Representativity}

\section{A. Representativity of the EU Social Partners}

Articles $138-139$ of the Treaty introduced a novel notion to the EU, whereby the social partners at the European level are assigned a significant and formal role in EU agenda setting, ${ }^{10}$ which the social partners carry out through a process of "social dialogue." The institutional mechanisms described in Articles 138-139 give the social partners a unique advantage relative to all other interest groups in the EU with respect to the development of EU social policy. The law-making process is twofold, consisting of both a consultative and a law-making stage. According to Article 138, the Commission must consult the social partners and invite them to comment on any proposal it submits that pertains to social policy. Following the consultation, the Commission may proceed one of two ways: it can invite the social partners to submit a comment or a recommendation on the Commission's draft of the legislative proposal, ${ }^{12}$ or it may accept a decision of the social partners to take the lead and draft the legislative proposal themselves. ${ }^{13}$ In the latter case, the social partners have the power to commence negotiations or collective bargaining, ${ }^{14}$ which should lead to a consensus on the formulation of a proposal

10. The social partners are involved in social dialogue on several levels, including sectoral and intersectoral dialogue and involvement in EU policy implementation. For a description of the multiple levels of their involvement, see, for example, Catherine Barnard, The Social Partners and the Governance Agenda, 8 Eur. L.J. 80 (2002). This article will focus on intersectoral EU agreements.

11. In various forms, EU social partners have long been involved in the EU law-making process. In the past, however, this involvement did not amount to legislative power. The expansion occurred through a long evolution of encouraging social partners' involvement in the EU law-making process. For a broad, yet thorough, description of the evolution of the EU social dialogue, see FranseEn, supra note 5, at 49-71.

12. The Council will go on to enact this proposal according to the ordinary legislative procedure established in article 251 of the EC Treaty, under the conditions set forth in article 137. This provides for a legislative process that involves both the Council and the European Parliament.

13. EC Treaty, supra note 4, arts. 138(4), 139.

14. I use the term collective bargaining despite the difficulties in applying the term on the European level. Note that there is an inherent dissimilarity between collective bargaining on the national level, when labor and management are operating in a sphere in which both can assume relatively balanced power relations, and the European level. On the European level, labor is "de facto deprived 
for community action. If the social partners choose this course of action, the Parliament and the Commission cannot interfere and are obligated to await the results of the social dialogue. Article 139 stipulates the process for the implementation of the agreed proposal, either by a decision of the Council or at the national level. ${ }^{15}$ To date, the Council has granted binding effect to several intersectoral and sectoral agreements reached by the social partners. ${ }^{16}$

While no official document defines the organizations authorized to sign EU cross-sectoral collective agreements, in practice, three organizations-the European Trade Union Confederation (ETUC) on the side of labor, the European Centre of Enterprises with Public Participation (CEEP) and the Union of Industrial and Employers' Confederations of Europe (UNICE) on the side of management-have traditionally played a dominant role on the cross-European level and have been regarded as the EU's social partners. In fact, Jacques Delors, the European Commission President, invited these organizations to the famous Val Duchesse Meeting

of its classic weapon of industrial action that is the strike." Stijn Smismans, The European Social Dialogue Between Constitutional and Labour Law, 32 EUR. L. REV. 341, 358 (2007). Collective bargaining on the EU level is a very particular kind of collective bargaining-one in which labor is in a rather weak position vis-à-vis management. See, e.g., Wolfgang Streeck, Neovoluntarism: A New European Social Policy Regime, in Governance in the European UnION 64 (G. Marks et al. eds., 1996). This fundamentally alters the process of collective bargaining as it weakens the labor position, and the process has been termed "bargaining in the shadow of the law." Brian Bercusson, European LABOUR LAW 538 (1996). Under such circumstances, there is clear justification for some intervention by the public authorities, the Commission, and the Council, as compared to the more plural, laissezfaire system. Smismans, supra, at 358 . In addition, the Commission has provided substantial financial support to the EU social partners, which is unique and unacceptable on the national level. This is also justified by the distinctiveness of EU "collective bargaining." FRANSEEN, supra note 5, at 78. For a systematic exploration of the theoretical framework for EU collective bargaining, see, for example, Antonio Lo Faro, Regulating Social Europe (Rita Inston trans., 2000).

15. EC Treaty, supra note 4, art. 139(2). The "route" of implementing agreements autonomously through national industrial relations processes renders these agreements exterior to Community law and lacking generally binding status. This article will focus on the route of implementation through Council Directive. For a discussion of "autonomous implementation," and in particular the claim that in practice the use of EU social dialogue has shifted from implementation by Council Directive to implementation through autonomous processes, see Smismans, supra note 14, at 342-46. Despite the recent increase in "autonomous implementation" and the shift toward more "self reporting systems," the future of more autonomous EU social dialogue is still uncertain, as Smismans notes.

16. The scope of this research is confined to intersectoral agreements that serve as the basis for future EU directives. For a recent discussion on the various types of sectoral and intersectoral agreements to date and their binding nature, see generally Stijn Smismans, The European Social Dialogue in the Shadow of Hierarchy 28 J. Pub. POL. 161 (2008). Note that the focus on these types of agreements, strong agreements, shifts the emphasis to the constitutional model rather than the "labor law model," to use Bercusson's terminology, of the EU social dialogue. Bercusson, supra note 14, at 523. 
that set the stage for the new social dialogue in 1985. Not surprisingly, these organizations negotiated and signed the first European social dialogue agreement, relating to parental leave. ${ }^{17}$ This agreement was challenged in the UEAPME case.

While academic literature typically questions the representativity of labor organizations, the European Association of Craft, Small and Medium-Sized Enterprises (UEAPME) in that case claimed that additional negotiators should be added to the EU social dialogue in order to render it representative. UEAPME, which had not taken part in negotiating the parental leave agreement, challenged the legality of the Council's directive to implement it. Specifically, UEAPME questioned the democratic legitimacy of the agreement, and UEAPME argued that the negotiations that led to the agreement were not representative of the interests of the relevant employers because the interests of small and medium-sized enterprises were not taken into account. In short, UEAPME requested access to the negotiations - a seat at the table-as a participant in the EU social dialogue.

The CFI acknowledged the importance of representativity in EU social dialogue. It ruled that in the process of implementing EU framework agreements, the Council and Commission are required to pass judgment on whether the EU social partners achieved "sufficient collective representativity." Only if sufficient collective representativity is achieved will the agreement in question become an EC directive. The CFI thus legitimized judicial review of the Council and Commission's assessment of sufficient collective representativity without specifying clearly the particular standards for determining such representativity.

In the UEAPME case, the CFI declared that the EU social partners had achieved sufficient collective representativity, which conferred upon them the requisite democratic legitimacy to make an agreement forming the substance of a legally valid EC directive. ${ }^{18}$ However, as no clear standards were established to guide future cases, this case provides more questions than answers. The difficulty in clearly defining representativity is further complicated by the multifaceted nature of representativity.

Representativity is a disputed concept. One established measure for determining representativity is the numbers criterion, which refers to the recognized number of members of a group relative to the potential number of constituents represented by the group. The CFI's conceptualization of representativity did not stress the cri-

17. Council Directive 96/34, 1996 O.J. (L 145) (EC).

18. Case T-135/96, UEAPME, 1998 E.C.R. II-2335. Despite the legal judgment, this case resulted in a cooperation agreement between UNICE and UEAPME, whereby UEAPME became a recognized participant in the European social dialogue. 
terion of numbers represented $;^{19}$ instead, it was more concerned with the question of whether the relevant interests were taken into consideration. ${ }^{20}$ One method of ensuring that all relevant interests are present is to convene all of the groups that represent the variety of interests at the negotiating table. In light of the UAEPME case, this method was the focus of the CFI's decision. However, the internal governance structure of the organizations was not considered as an intrinsic element of representativity. ${ }^{21}$ In other words, a thorough inquiry regarding the adequate representation of any particular interest should examine another aspect of representativity, namely, the degree to which the constituencies actually have control over the decisions made by their group's leaders. Recognizing this element of representativity may entail examining features of internal functioning, such as the democratic nature of the elections for the organization's leadership or the decision-making processes that the organization implements. Without suitable internal structures that provide the group's constituents with a sufficient degree of control, attendance at the table alone cannot ensure adequate representation of the interest at hand.

In the UAEPME case, the court directly addressed only one of the basic aspects of representativity-the number of groups participating in the negotiations. Indirectly, however, the UAEPME case revealed the gap between the attendance criterion and the question of the internal functioning of the group. Conversely, the criterion of internal functioning could also serve to exclude groups from the negotiations. Thus, participation and internal functioning are simultaneously entwined and in tension due to the risk of their mutually contradictory implications.

\section{B. Representativity and Regulatory Autonomy}

A definition of representativity that takes into account the internal functioning of groups faces the additional challenge of preserving the regulatory autonomy of the

19. Compare the CFI understanding with the European Agreement on the Organization of Working Time of Mobile Staff in Civil Aviation, where the Commission counted the number of workers/employers covered by the signatory parties to the agreement. Council Directive 2000/79, arts. 1-5, 1996 O.J. (L 302) (EC). See FRANSEEN, supra note 5, at 197. This criterion is important but not sufficient to establish representativity.

20. For a recent discussion, see Smismans, supra note 14 , at 350.

21. See, e.g., Marlene Schmidt, Representativity-A Claim Not Satisfied: The Social Partners' Role in the EC Law-Making Procedure for Social Policy, 15 INT'L J. CoMP. LAB. L. \& INDUS. REL. 259 (1999) (claiming that the representativity of the EU social partners depends on their internal decision-making processes). But see FrANSEEN, supra note 5, at 199. Franseen advocates democratic internal decision-making processes as a criterion for representativity for EU social partners that create EU law, although she regards it as more of an issue of the mandate of the signatory partners. 
social partners. In this vein, Brian Bercusson, a prominent scholar of EU law, has drawn attention to the potential of the UEAPME case to infringe on the autonomy of social partners, despite the CFI's unequivocal confirmation of such autonomy. ${ }^{22}$ Bercusson raises concerns regarding the scope of the Commission's mandate to intervene in the social dialogue. In particular, he is concerned by the fact that the scope of intervention in the internal mechanisms of the social partners remains vaguely defined. Thus, for example, Bercusson asks whether the Commission is even allowed to intervene in a case in which the ETUC approves an agreement based on a majority vote, but the largest national trade union confederation has voted against it. ${ }^{23}$ This example demonstrates that the internal functioning of an organization, in this case its decision-making process, may result in a unrepresentative decision. Another hypothetical situation Bercusson contemplates is one in which the national confederations determine that the social partner has exceeded its mandate. ${ }^{24}$ What should the Commission's position be, given a social partner that has altered-in a democratically dubious manner - the constitutional arrangements required for the election of its leading bodies? Should the Commission intervene in such situations? Would such intervention even be permissible? The answers to these questions hinge on the particular understanding of the meaning of representativity.

The tension between the desire to preserve maximum autonomy of the social partners on the one hand, and to ensure sufficient representativity on the other, is echoed in the more general debate regarding the participation of civil society in national and transnational public spheres. While the participation of civil society in governance structures, particularly on the transnational level, is one of the dis-

22. Brian Bercusson, Democratic Legitimacy and European Labour Law, 28 INDUS. L.J. 153, 158-63 (1999). Bercusson refers to ILO Conventions Nos. 87 and 98, in addition to the recognized constitutional traditions of the member states, as a source for the principle of regulatory autonomy. Id. at 163. However, as I note, despite the superiority of regulatory autonomy in these Conventions, a thorough analysis of the jurisprudence of the ILO Freedom of Association Committee shows that one can discern an undercurrent in the Committee's conceptualization of the norm by which competing principles, such as the internal functioning of organizations, can mitigate regulatory autonomy under appropriate circumstances. See Faina Milman-Sivan, Freedom of Association and the ILO: Towards a Normative Framework, 3 L. \& ETHICs HuM. RTs. (forthcoming 2009). This justifies a view that these Conventions incorporate a balance between the principle of regulatory autonomy and other competing principles.

23. Bercusson, supra note 22, at 161; see also Brian Bercusson, Labour Law 24 (Citizenship and Democratic Legitimacy in the European Union, 2005), http://www.arena.uio.no/cidel/Worksho pStockholm/Bercusson.pdf ("[A]ttention must be paid to the internal institutional dynamics of the social partners, UNICE in particular. Experience has demonstrated the importance of the social partners' internal constitutional procedures.").

24. BERCuSSON, supra note 14 , at 161. 
tinctive characteristics of the contemporary era, it is persistently challenged on democratic grounds. Civil society is often viewed as a tool for advancing democracy. Opponents, however, have been known to turn civil society advocacy on its head, attacking civil society groups themselves for being undemocratic, unrepresentative, and unaccountable. ${ }^{25}$ The significant emphasis of the EU civil society debate on accountability, particularly the concern that constituents do not have sufficient control over decisions made by civil society, resonates with the internal functioning aspect of representativity of the EU social partners.

Discussing the representativity of the EU social partners in terms of advancing or regressing democracy simultaneously underscores the significance of the internal functioning of groups and injects new urgency into the debate. Understanding EU social dialogue as part of the EU's democracy-enhancing efforts mandates that the issue of representativity in general, and that of internal governance structures in particular, be given careful consideration. Arguably, in light of the recent "legitimacy crisis" in the EU, ${ }^{26}$ the need to address the representativity issue is becoming increasingly urgent. ${ }^{27}$

\section{EU Social Dialogue as a Component of EU Democratic Governance Structure}

Regardless of the intentions of the founders of EU social dialogue, ${ }^{28}$ the EU social dialogue is in many respects viewed in terms of its contribution to achieving a more democratic governance structure in the EU. From this perspective, how-

25. See infra notes $46-57$ and accompanying text.

26. It is widely held that the recent rejections of the EU Constitution may be seen as a sign of a severe legitimacy crisis in the EU. See, e.g., Ireland Rejects EU Reform Treaty, BBC News, June 13, 2008, http://news.bbc.co.uk/2/hi/europe/7453560.stm.

27. But see Olaf Deinert, Modes of Implementing European Collective Agreements and Their Impact on Collective Autonomy, 32 InDus. L.J. 317, 318 (2003), which states that with the strengthening of the UEAPME position in EU social dialogue, there is a view that the practical urgency of the question has diminished. Despite the unlikely prospect of organizations filing cases similar to the UEAPME case, the core problem of representativity, viewed from the EU democratic deficit crisis perspective, seems more pressing than ever.

28. There are clear indications that the main reason for the establishment of the EU social dialogue was to circumvent the British veto on most social policy subjects on the EU level. Bercusson goes as far as declaring that British Prime Minister Margaret Thatcher is the mother of EU social dialogue when he states that, "[s] he halted the programme of EU social legislation which was the result of the Social Action Programme of 1974. The then Treaty requirement of unanimous voting in the Council allowed her to veto the Commission's social policy proposals. It was this inability to launch a social dimension of the Single European Market through the legislative channel which stimulated the effort to find an alternative." BERCUSSON, supra note 14 , at 5 . 
ever, the EU social dialogue can lead to two contradictory claims. The first is that such dialogue is an important step toward incorporating a broader array of interests and groups in the formulation of EU social policy, thereby strengthening both participatory democracy and the legitimacy of the EU process as a whole. ${ }^{29}$ The other approach perceives such dialogue as unrepresentative and underinclusive, and thus as a mechanism that fails to enhance EU democracy. ${ }^{30}$

European institutions, especially the Commission, viewed the EU social dialogue as an important step toward better representation in the EU, and thus a positive contribution to counterbalance the widely discussed EU democratic deficit. ${ }^{31}$ Many scholars who study democratic features of the European Union agree that the EU does suffer from such a democratic deficit, ${ }^{32}$ yet broad disagreement exists as to the appropriate strategy by which to strengthen the democratic legitimacy of the Union. ${ }^{33}$ The traditional account of the democratic deficit theory assumes that the EU suffers from the lack of a parliamentary model of representative democracy. ${ }^{34}$ However, the

29. See, e.g., Thomas Risse-Kappen, Exploring the Nature of the Beast: International Relations Theory and Comparative Policy Analysis Meet the European Union, 34 J. COMmON MKT. STUD. 53, 74 (1996).

30. See infra notes $46-49$ and accompanying text.

31. Franseen, for example, notes that the main reason that EU institutions supported EU social dialogue was probably to give more legitimacy to EU legislation by involving the representatives of management and labor in the European decision-making process. See FrANSEEN, supra note 5, at 71 .

32. See, e.g., Andreas Follesdal \& Simon Hix, Why There is a Democratic Deficit in the EU: A Response to Majone and Moravcisk, (Eur. Governance Papers, No. C-05-02, 2005), available at http://www.connex-network.org/eurogov/pdf/egp-connex-C-05-02.pdf. But note other opinions, claiming that no democratic deficit exists in the EU. See, e.g., Andrew Moravcsik, In Defense of the "Democratic Deficit": Reassessing Legitimacy in the European Union, 40 J. Common Mкт. STUd. 603, 621 (2002) ("When judged by the practices of existing nation states and in the context of a multi level system, there is little evidence that the EU suffers from a fundamental democratic deficit.").

33. See, e.g., Philippe C. Schmitter, How to Democratize the European Union and Why BOTHER? 10-11 (2000) ("Let us set aside the usual convenient 'theoretical' devices for constituting an acceptable democratic polity. No impartial outside législateur is going to appear providentially and produce a solution based on such compelling abstract principles that the design of the Euro-democracy will be recognized by all as an obvious emanation of the 'General Will of Europe'.... If and when the Euro-polity gets down seriously to the task of filling its democracy deficit, it will be a much messier affair . . the participants are going to have to resolve some rather formidable practical dilemmas ...."); Thomas W. Pogge, Creating Supra-National Institutions Democratically: Reflections on the European Union "Democratic Deficit," 5 J. PoL. PHIL. 163 (1997) (proposing to remedy the democratic deficit in the process of EU institutional design by shifting some of the power to design the scope, domain, and procedures of $E U$ institutions and decision-making processes from the national politicians and experts to the citizens of the EU, thereby increasing citizen participation in policymaking).

34. See, e.g., Deirdre M. Curtin, Postnational Democracy: The European Union in Search of Political Philosophy 36-37 (1997). 
desirability of a majoritarian avenue for the $\mathrm{EU}$, that is, the promotion of state-like parliamentarism on the supranational level, has been called into question. ${ }^{35}$

Increasingly, in a parallel search for democratic legirimacy, academics have turned to civil society as a potential instrument for amplifying EU democracy. The White Paper on European Governance, published by the Commission and widely considered a landmark development, called for greater participation of civil society as a promising approach that can lead to enhancing the EU's legitimacy. ${ }^{36}$ Many welcomed this development, embracing the belief in the ability of civil society to improve good governance in the EU. ${ }^{37}$

Those who support the notion that civil society can alleviate the EU's democratic deficit have suggested various ways in which this could be achieved. First, civil society could help enrich the input into the EU decision-making process, and thus enhance the quality of policy and decision making and their effective realization. ${ }^{38}$ Second, as "agents of political socialization" ${ }^{39}$ for the EU citizenry, civil society participants in EU processes would effectively increase participatory democracy, while as an agent of political education, civil society activity could facilitate citizens' participation in the new political structures evolving in the EU. ${ }^{40}$ Third, civil society could help foster a Europe-wide public sphere, by providing not only a resource for educating the EU citizenry on European issues ${ }^{41}$ but also a platform for stimulating public deliberations in an effort to arouse Europe-wide public opinion. ${ }^{42}$

Finally, some view the role of civil society as an opportunity to give voice to

35. John Coultrap, From Parliamentarism to Pluralism: Models of Democracy and the European Union's "Democratic Deficit," 11 J. TheoretiCal. Pol. 107, 111-13 (1999); Renaud Dehousse, Constitutional Reform in the European Community: Are There Alternatives to the Majoritarian Avenue?, 18 W. Eur. Pol. 118, 125 (1995).

36. Commission White Paper on European Governance, at 15, COM (2001) 428 final (July 25, 2001) [hereinafter European Governance].

37. Oliver De Schutter, Europe in Search of Its Civil Society, 8 Eur. L.J. 198, 208-09 (2002).

38. Edgar Grande, Post-National Democracy in Europe, in Democracy Beyond the State? The European Dilemma and Emerging Global Order 115, 127-32 (Michael Th. Greven \& Louis W. Pauly eds., 2000). They could provide decision-making bodies with local, grassroots knowledge, which cannot be obtained in alternative ways, in addition to providing these bodies with particular expertise and skills, not always affordable to the governing authority. Moreover, in certain subject areas, civil society may be the appropriate agent for delivering services to people by managing projects funded by the EU. European Governance, supra note 36, at 14; see also Obradovic, supra note 8, at 374-77.

39. Alex Walleigh, "Europeanizing" Civil Society: NGOs as Agents of Political Socialization, $39 \mathrm{~J}$. Common MKt. STUd. 619, 621 (2001).

40. Id.

41. Grande, supra note 38, at 127-32.

42. Deirdre Curtin, Private Interest Representation or Civil Society Deliberation? A Contemporary Dilemma for European Union Governance, 12 Soc. \& Legal STUD. 55, 62-66 (2003). 
underrepresented groups and interests. Civil society could provide for a more inclusive discussion that enhances the general representativeness of the lawmaking process. ${ }^{43}$ EU governance structures thus would receive a more accurate and finetuned picture of the true interests of their constituents. Bringing all relevant voices and interests to the fore, including those that were previously underrepresented, will have a democratizing effect on the EU. Accordingly, civil society is seen as the appropriate vehicle to realize this end. To the extent that increased participation of civil society in EU institutions is viewed as a step toward strengthening democracy, empowering the social partners to participate in the drafting of EU social legislation is a bold move in this direction. ${ }^{44}$ This approach views EU social dialogue as a "legitimacy resource" of the EU.95

Critics, however, have doubted the ability of EU social dialogue to play a constructive role with respect to the democratic deficit. Some critics argue that this process eliminates the European Parliament, thereby diminishing representative democracy and rendering the process inadequate. ${ }^{46}$ More importantly, some scholars contend that the strengthening of "social dialogue" could contribute to the legitimacy of the EU only if the social partners themselves are representative and function democratically. ${ }^{47}$

These critiques resonate with the more general debate over the participation of civil society groups in the EU and demand review and a deeper understanding of representativity. Similar to the arguments made about the EU social dialogue, some scholars challenge the democratic quality and internal functioning of civil

43. Participation is considered one of the key principles of good governance in the White Paper. See European Governance, supra note 36, at 14.

44. The CFI in the UEAPME case cites the social dialogue as a means to assure "the participation of the people" in the absence of the European Parliament. Case T-135/96, UEAPME, 1998 E.C.R. II-2335, Il 89.

45. For a discussion of EU collective bargaining as a "legitimacy source," see Lo FARO, supra note 14 , at $138-45$.

46. Obradovic notes that the European Parliament maintains an ambiguous position as to the EU social dialogue. It believes that the parliamentary system of representation is the best way to achieve democracy in the EU. Nevertheless, it regards the social partners as positive contributors to social policymaking, as they bring social policy closer to the EU's citizens. It further believes, however, that the role of the European Parliament in such social dialogue should be enhanced through active incorporation into some of the processes conducted by social partners. See an analysis of EU Parliament's attitude toward the EU social dialogue in Obradovic, supra note 8, at 362-66.

47. Id. at 357; Annalisa Reale, Representation of Interests, Participatory Democracy and Lawmaking in the European Union: Which Role and Which Rules for the Social Partners? 20-21 (Jean Monnet Working Paper, No. 15/03, 2003), available at http://www.jeanmonnetprogram.org/papers/03/031501.html. 
society organizations in general. ${ }^{48}$ Such criticism asks not only who should participate but also how extensive the democratic processes of participating groups should be. A fundamental justification for formally including functional groups in legislative processes relies on the assumption that such participation better guarantees the input of all relevant interests and voices. This rationale is undermined if reservations are had as to the representativeness of the participating organizations. If some interests are neglected while others receive excessive consideration, this actually contributes to the delegitimization of the EU as a norm-generating structure, as reflected in Schmidt's view that European governance can be characterized as governance with some of the people. ${ }^{49}$

Further concern is expressed with relation to the internal structures of civil society. For example, the structural remoteness of EU federation organizations from their grassroots constituencies and, therefore, from local preferences has recently been pinpointed as a factor that weakens representation. ${ }^{50}$ In addition, questions are raised regarding the accountability of EU civil society to its constituents, with initial evidence indicating that, in fact, it is not held accountable in any way. ${ }^{51}$

While a full analysis of this debate is beyond the scope of this work, several additional prominent arguments against such participation should be mentioned. Some scholars question the ability of civil society to perform the functions attributed to it. ${ }^{52}$ Paul Magnette, for example, questions the assertion that involvement of functional interests_-as opposed to representative democracy-necessarily contributes to active citizenship..$^{53}$ Others raise pragmatic objections; for example, one objection concerns the feasibility of incorporating civil society into the decision-making process in a workable fashion. Oliver De Schutter even proposes an alternative model titled "committed consultation." This model establishes a practical and feasible pro-

48. See, e.g., Warleigh, supra note 39.

49. See Sandra Kroger, Nothing but Consultation: The Place of Organised Civil Society in EU Policymaking Across Policies 30 (Eur. Governance Papers, No. C-08-03, 2008), available at http://www .connex-network.org/eurogov/pdf/egp-connex-C-08-03.pdf. Evidence shows that the access of civil society to the EU is biased, and tends toward European umbrella organizations, based in Brussels, with strong constituencies in larger and older member states, and toward business. Id. at 31 .

50. See id. at 31 .

51. See id. at 32.

52. See generally Warleigh, supra note 39.

53. Paul Magnette, European Governance and Civic Participation: Beyond Elitist Citizenship?, 51 POL. STUD. 144, 148 (2003). He makes a clear distinction between general participation that indeed raises civic consciousness and the participation of organized interests, which does not contribute to the legitimacy and democracy of the EU, but merely amounts to "broader" neo-corporatist structures, which include more shareholders than the social partners. Id. 
cess of consultation that affords real power to civil society, ${ }^{54}$ yet does not entail full formal participation. It therefore seeks to ensure that it is the democratically-elected representatives who are ultimately responsible for the decisions.

Preserving the internal autonomy of civil society organizations is even more pertinent in the general debate regarding civil society's participation in EU governance. The complexity of the issues involved can be seen in the recent attempt to establish public norms related to the internal functioning of civil society. These norms were introduced as voluntary "Codes of Conduct." The recent Code of Conduct adopted by the Commission on May 28, 2008 and launched on June 23, 2008 may be considered an attempt to regulate civil society while maintaining its independence..$^{55}$ Yet, can such voluntary codes mitigate the dilemma with regard to the social partners? EU social partners have specific concerns that they must contend with. For example, the social partners may be reluctant to establish a legal entity, fearing subjection to lawsuits following a call to strike. ${ }^{56}$ Given the distinctive role of social partners, their unique territorial scope, and the exclusive authority granted them through European social dialogue, the sufficiency of such general codes to successfully regulate civil society organizations appears dubious. ${ }^{57}$ This underscores the need to establish guidelines and principles for social partners that, at the very least, conform to the general norms of labor law. This is in fact the approach taken by the ILO, as the following section observes.

54. The basic assumption of this model is that consultation without the right to receive an answer remains on the formalistic level, and thus cannot genuinely contribute to the democratic legitimacy of the EU. Instead, this model imposes an obligation on the governing institutions to listen and answer the representative organizations in each field. These organizations will further receive the right to not only receive an answer but also to apply for judicial review in cases in which they believe that the answer they have received is not satisfactory. De Schutter, supra note 37, at 214.

55. Commission Communication on the European Transparency Initiative (A Framework for Relations With Interest Representatives), COM (2008) 323 final (May 27, 2008).

56. See FranseEn, supra note 5, at 43.

57. This does not mean that one could not imagine "regulation" based on a voluntary or semi-voluntary basis. Creating a structure where "new governance" tools are used to create improvement of internal functioning, as suggested by Jonathan Zeitlin, for example, might be envisaged. See Jonathan Zeitlin, Social Europe and Experimentalist Governance: Towards a New Constitutional Compromise? (Eur. Governance Papers No. C-05-04, 2005), available at http://www.connex-network.org/eurogov/ pdf/egp-connex-C-05-04.pdf. Such a process, based on benchmarking, learning, and reporting, could be compatible with the recent practice of the EU social partners to produce "new generation texts" that incorporate similar measures. Smismans, supra note 16, at 172.Thus, the criterion of appropriate internal functioning in "representativity" would perhaps mean, under such a system, requiring EU social partners to participate in such "new governance" self-evaluation schemes. 


\section{Turning to the ILO: Exploring Similarities and Differences}

In recent years, the ILO has encountered substantial pressure to reassess its institutional design. Two lines of attack have been particularly significant, both encompassing arguments that hinge on representativity.

One line of criticism addresses the ILO's emphasis on reforming national policy and, in particular, national law. It questions the state-based representation of worker and employer organizations in the ILO.58 Underpinning the current framework for international industrial relations are the conceptions and goals that prevailed after World War II, particularly as embodied in the Bretton Woods system. Realizing the destabilizing effects of international economic forces on national economy and social justice, ${ }^{59}$ the designers of the Bretton Woods system promoted the economic independence of the nation-state. ${ }^{60}$ In doing so, the designers hoped to ensure the ability of each nation-state to engage in the advancement of social welfare programs and robust industrial relations systems, in order to facilitate political and economic stability. ${ }^{61}$ Thus, the Bretton Woods international system was devised to promote national autonomy in the realm of industrial relations. ${ }^{62}$ Accordingly, the ILO was one of the international organizations that promoted and supervised industrial norms and labor standards, thereby encouraging their incorporation and enforcement on the national level. ${ }^{63}$ In view of the processes occurring in the "global era," and, in particular, the weakening of

58. The ILO Conference, the body that establishes and adopts International Labor Standards, is composed of four delegates from each member state. Each state is represented by two governmental delegates, one representative of employers' organizations and one delegate of employees' organizations.

59. Interwar currency instability was seen as the effect of speculations, and John Maynard Keynes, Britain's chief negotiator, contended that national monetary autonomy was essential for the successful achievement of economic policy geared to full employment. See, e.g., John B. Goodman \& Louis W. Pauly, The Obsolescence of Capital Controls?: Economic Management in an Age of Global Markets, 46 WORLD POL. 50 (1993).

60. See David M. Trubek et al., Transnationalism in the Regulation of Labor Relations: International Regimes and Transnational Advocacy Networks, 25 LAW \& Soc. INQUIRY 1187, 1190 (2000).

61. The United Nations was conceived as the constituent that would promote just international order and the goals of stability and economic welfare were codified in Article 55 of the U.N. Charter.

62. At the same time, international trade was promoted in order to achieve both efficiency (enabling production factors to focus on their most productive use, in accordance with the neo-liberal "international trade theory") and peace (the promotion of peace would be achieved through promoting interdependency). These policies were structured so as not to intrude on the independence of the state.

63. Trubek et al., supra note 60, at 1190. 
the nation-state in the economic arena, this approach is now being questioned, as is the state-based representation of functional interests.

The second line of criticism that the ILO has had to address relates to the issue of representativity, specifically in terms of the incorporation of civil society into its unique tripartite structure. By incorporating two particular functional interests from each member state, those of the workers and those of the employers, the tripartite structure of the ILO departs from international organizations' conventional state-centered form of representation. This tripartite structure has been criticized for its focus on class alone, privileging the interests of the developed Northern countries and ignoring the concerns of developing countries.

Indeed, critics of the tripartite structure claim that the ILO is dominated by European trade unionists reflecting Western values that exclude the voices of workers in developing countries. ${ }^{64}$ According to this line of criticism, the tripartite structure reflects the historical arrangement pertaining solely to social democratic governments, which consider class to be the privileged form of organization that best represents the typical male, full-time, organized worker. ${ }^{65}$ However, only a fraction of the world's workers (mostly in the North) are organized in some fashion, and the current structure excludes the voices and interests of groups, such as migrants, women (who have recently entered the workforce), unemployed workers, temporary workers, and the large and ever-growing informal sector. ${ }^{66}$

In response, the ILO has reaffirmed its commitment to the tripartite repre-

64. See generally Sean Cooney, Testing Times for the ILO: Institutional Reform for the New International Political Economy, 20 Comp. LAB. L. \& PoL'Y J. 365 (1999).

65. See Abdul-Karim Tikriti, Tripartism and the International Labour Organization 16 (1982) (The true meaning of the tripartite principle was defined in terms of Western capitalistic societies, where a clear distinction exists between employers, workers, and governments.).

66. Georg Nolte and Sergey Lagodinsky discuss the reasons for raising the question of representativeness of the tripartite system and note:

The quantitative reason is the decline in the membership in union and employer organizations in developed countries. In 1995, only 164 million of the world's estimated 1.3 billion workforce belonged to trade unions, with a membership rate in more than half of the ILO member countries falling to less than 20 percent of the workers. The employers' organizations are struggling with similar membership problems. The qualitative deficit of the present tripartite system lies in the fact that some of the disputed issues are dealt with without substantive and sufficient representation of the relevant groups. This is true in particular for the indigenous people, as well as unemployed and migrant workers.

Georg Nolte \& Sergey Lagodinsky, The Role of Non-Governmental Organizations in the International Labor Organization, in The Welfare State, Globalization, and InTERnational LaW 321, 336 (Eyal Benvenisti \& Georg Nolte eds., 2004). 
sentational structure that includes governments, employers, and workers while engaging in a discourse with non-governmental organizations (NGOs) (civil societies beyond trade and workers' organizations). From the perspective of formal inclusion in the ILO, the discourse with the NGOs amounts to little more than rhetoric, as evidenced by statements such as that of the Director-General, Juan Somavia, ${ }^{67}$ asserting that the ILO should link up with outside actors. Apart from consultative relations and ad hoc cooperation on particular projects, ${ }^{68}$ to date the ILO has denied the NGOs a formal role in its law-making processes.

The ILO has sought to strengthen its control over the workers' and employers' organizations of ILO members. In doing so, it reformed and strengthened the Credentials Committee (CC), the body that has played the crucial—albeit academically unscrutinized-role of gatekeeper to participation in the full deliberative processes of the organization. Until these reforms, the CC's role was largely technical, examining merely the extent to which the nomination procedures conformed to the ILO Constitution. ${ }^{69}$ The substantial reforms that the committee is currently undergoing (the 2005 reforms) indicate that the ILO has modified its expectations as to the

67. ILO, Report of the Director-General, ILO Doc. GB.280/18 (Mar. 2001).

68. For example, in the CoopAfrica project, launched in 2007, the ILO assists cooperatives to improve their governance, efficiency, and performance in order to strengthen their capacity to create jobs, access markets, generate income, reduce poverty, provide social protection, and give people a voice in society. On this project, the ILO is cooperating with the International Cooperative Alliance (ICA), which is the umbrella organization of the international cooperative movement and is the largest non-governmental organization (NGO) in the world. Cooperative Facility for Africa-CoopAfrica, http://www.ilo.org/global/What_we_do/Projects/lang-en/WCMS_096 164/index.htm (last visited Sept. 2, 2008).

69. For a full analysis of the traditional role of the Credentials Committee (CC) and its recent transformations, see Milman-Sivan, supra note 2. It is interesting to note that the Permanent Court of International Justice limited the mandate of the CC in a historic judgment in 1922. Due to the complexity of the CC's task, the Council of the League of Nations requested an advisory opinion from the Permanent Court of International Justice, in order to clarify the content of Article 3(5) of the ILO Constitution, which requires member states to "nominate non-Government delegates and advisors chosen in agreement with the industrial organizations, if such organizations exist, which are the most representative of employers or workpeople, as the case may be, in their respective countries." ILO Constitution art. 3 (June 18, 1919), available at http://www.ilo.org/ilolex/english/co nstq.htm. This opinion, issued in 1922, established the foundation for interpreting this constitutional provision and the basis for subsequent precedents. The Court rejected the contention of the Netherlands Confederation of Trade Unions that it was the most representative trade union organization in the country, and did not give its consent to the nomination of the non-governmental delegates. "Organizations" in this context was construed by the Permanent Court of International Justice to permit the inclusion of multiple organizations. Designation of the Workers' Delegate for the Netherlands at the Third Session of the International Labour Conference, Advisory Opinion, 1922 P.C.I.J. (ser. B) No. 01 (July 31). The Netherlands preferred to consult three other trade organizations that together consti- 
functional organizations that make up its tripartite structure-a step that may be viewed as a response to the above-mentioned critique. ${ }^{70}$ These expectations now encompass a minimal degree of adherence to the norm of freedom of association, as evidenced by the changes to the $\mathrm{CC}$ mandate. The 2005 reforms granted the $\mathrm{CC}$ power to refer complaints concerning violations of freedom of association to the Committee on Freedom of Association. ${ }^{11}$ Further, the Committee now has granted follow-up authority; that is, in severe cases of repeated violations of freedom of association, it can now require governments to file a follow-up report on such matters. Moreover, the Committee may now unanimously propose the monitoring of any situation concerning appropriate nomination procedures. These new provisions further extend the mandate of the $\mathrm{CC}$ to situations in which states deliberately avoid giving credentials to delegates of functional groups. ${ }^{72}$

The ILO's approach in both responses can be understood as coping with the criticism by tackling the deeper aspect of representativity. The first response of the ILO can be interpreted as a rejection of the notion that enhanced representativity requires the formal incorporation of additional civil society NGO members into its governance structure. In fact, the reaffirmation of its commitment to the tripartite governing structure constituted a rejection of the claim that representativity should be addressed by bringing more groups to the decision makers' table. In contrast, the second response may be viewed as strengthening the internal functioning aspect of representativity, by providing better guidance to the functional organizations as to their internal structure. The CC's 2005 reforms signified a departure from the ILO's long-standing position, which had explicitly rejected the suggested link between freedom of association and the criteria for recognizing functional groups. This prior approach can be partly explained by pressures to accommodate the ideological divide between capitalist and commu-

tuted the most representative organizations, and this nomination was allowed. See EBERE OSIEKE, Constitutional Law and Practice in the International Labour Organisation 65 (1985).

70. See Milman-Sivan, supra note 2, manuscript at 24-27.

71. The Committee on Freedom of Association (CFA) is the tripartite committee of the ILO Governing Body responsible for the examination of complaints alleging violations of freedom of association. Even before the reforms, a large majority of situations submitted to the $\mathrm{CC}$ for examination were simultaneously the object of procedures before the CFA. Likewise, it was not unusual for the CFA to receive complaints following the examination of cases by the $\mathrm{CC}$, particularly when it concluded that the problems fall principally within the competence of that Committee. ILO Governing Body, The Role of the Credentials Committee, II 27-28, ILO Doc. GB.286/LILS/3 (Mar. 2003).

72. ILO Governing Body, Report of the Committee on Legal Issues and International Labour Standards, app. I, arts. 5(2)(b), 26, ILO Doc. GB.289/11 (Mar. 2004). 
nist industrial relations during the Cold War. ${ }^{73}$ The ILO feared that the need to scrupulously examine participating groups' legitimate representation would infringe upon the organizations' ostensible commitment to include all member states and their delegates in ILO discussions. ${ }^{74}$ While the purpose of this accommodating approach-preventing exclusion of states from participation in the ILO- was achieved, it subsequently diminished the legitimacy of the $\mathrm{CC}$ and has had a detrimental effect on the ILO.

Adopting freedom of association as a guiding criterion for the CC's work opened the door to a more complex understanding of representation and representativity. ${ }^{75}$ This conceptualization emphasizes that representativity depends not merely on the "density criteria" (does the organization purport to represent a sufficient number of constituents?), but also on the represented organizations' appropriate internal functioning (ensuring that the constituents have sufficient control within their groups) ${ }^{76}$

The connection between freedom of association and the internal functioning of groups is clear. It is apparent that a workers' organization whose internal functioning was not guided by such a norm would be incapable of advancing the true interests of its members, an essential goal of the functional organization as described in Conventions Nos. 87 and $98 .{ }^{77}$ Convention No. 98 aims to protect work-

73. Int'l Labour Conf., Record of Proceedings, at 436 (1954).

74. See, for example, the government delegate from Argentina's speeches and the worker's delegate from India. Id. at 321-24. See also the speech of the government delegate of Ceylon. Id. at 326.

75. See generally Milman-Sivan, supra note 2, for this analysis regarding the ILO. Conceptualizing the examination of credentials in terms of freedom of association means abandoning the traditional formalistic approach of the ILO, which has centered on the delegates having formal authority to act. For a discussion of representation as having formal authority to act, see HANNA F. Pitkin, The Concept of Representation 38, 39 (1972).

76. Note that while theoretically this concern applies equally to labor and management, in practice it escalates on the labor side. As Supiot explained:

On the management side the true power is at the bottom, held by member companies which, in possession of the real economic power, conceive of collective representation along the lines of the mandate model in civil law: the representative is, then, actually a proxy unable to exceed the bounds of the power with which he is vested. On the labour side, the "bottom" has no power of its own or decision-making autonomy economically speaking, except in the form of "wildcat strikes", whose lawfulness is not, moreover, always recognized everywhere. It is the representative, then, more than the principals, who actually holds the power in the organisation.

Supiot Report, supra note 5, I 487.

77. The most significant and detailed substantive standard for freedom of association was elaborated on in two ILO Conventions, Freedom of Association and the Right to Organize Convention 1948 (No. 87) [hereinafter Convention No. 87] and the Right to Organize and Collective Bargain- 
ers and workers' organizations from anti-union discriminatory policies and seeks to guard against other damaging forms of interference in the functioning and administration of workers' organizations. ILO Convention No. 87 also provides for certain functional and organizational freedoms that such representative organizations must enjoy. These include the right to draw up their own rules and constitutions, elect representatives, organize administration and activities, and formulate programs. ${ }^{78}$ The jurisprudence of freedom of association in the ILO is the result of a balance struck between the need to preserve regulatory autonomy and the need to promote the free will of the organizations' members.

The ILO found it necessary to allow supportive legislation regulating the internal functioning of worker organizations when such regulation serves to advance freedom of association itself as a means to "guarantee democracy." for example, the ILO has allowed state regulation to intervene in the regulatory autonomy of workers' organizations in the context of voting procedures related to constitution drafting within the organizations. Legally enforcing the practices of secret ballot, direct voting, and majority vote ${ }^{80}$ on issues that touch upon constitutive practices of the organization ${ }^{81}$ was deemed appropriate for state legislation, because the objective of this intervention was to guarantee democracy. ${ }^{82}$ Government-mandated term limits for union executive bodies are also permissible. ${ }^{83}$ Such regulation is considered a measure that ensures—rather than inhibits—freedom

ing Convention 1949 (No. 98) [hereinafter Convention No. 98]. The vast jurisprudence of the Governing Body's CFA and the reports of the Committee of Experts on the Application of Conventions and Recommendations elaborate this standard. For a deep analysis of CFA jurisprudence as a plausible normative basis for the recent reforms in the ILO, see Milman-Sivan, supra note 22.

78. ILO, Freedom of Association and Protection of the Right to Organise Convention art. 3 (Sept. 7, 1948). Convention No. 87 also affirms the right of all workers and employers to establish and join an organization of their own choosing, without prior authorization by the state, and provides for the right of workers' organizations to establish and join federations and confederations, and to affiliate with other international workers' and employers' organizations. It further provides that administrative authority shall not weaken these guarantees. Id.

79. See ILO, Comm. on Freedom of Ass'n, Report 197: Chile (Case No. 823), I 382, ILO Doc. LXII (ser. B) No. 3 (Nov. 1979) [hereinafter Report 197]; ILO, Comm. on Freedom of Ass'n, Report 294: Lebanon (Case No. 1704), Il 156, ILO Doc. LXXVII (ser. B) No. 2 (June 1979) [hereinafter Report 294].

80. ILO, Comm. on Freedom of Ass'n, Digest of Decisions, II 378 (2006) (principles relating to legislation in this respect and interference by the authorities).

81. See Report 197, supra note 79, I 382. This case involves a complaint against the Government of Chile, which required such a majority in Article 18 of its trade law legislation.

82. Report 294, supra note 79, II 156.

83. ILO, supra note 80 , I 396 . However, it also states that "it should be left to the unions themselves to set the period of terms of office." Id. \ 397. 
of association, by guaranteeing the rights of workers to freely participate in matters that affect the very existence and structure of their organizations. ${ }^{84}$ This brief and partial summary of the ILO jurisprudence of freedom of association reflects a strong commitment to the autonomy of the social partners and, at the same time, to the internal normative compromise the ILO has made between such autonomy and the principle of intervention in the internal functioning of groups. The 2005 reforms open the door to a state of affairs whereby in the future, under a deliberative reading of the norm of freedom of association, a more democratic and deliberative internal structure could lead to more interests being represented through the existing functional organization. ${ }^{85}$ This remains a distant vision; it is too early to assess the full scope and impact of the CC's reforms. It is not, however, too early to consider whether the EU can learn from the ILO approach.

\section{What Can The EU Learn From The ILO?}

Before elaborating on the lessons from the ILO case, it is worthwhile to underscore some similarities between these two institutions in terms of their social policymaking practices. While both institutions indulge in a "civil society discourse," declaring the need for cooperation with civil society institutions, in fact, their system of law production affords formal legislative powers only to employer and employee civil society organizations. It is therefore doubtful that the EU can learn from the ILO how to better engage NGOs ${ }^{86} \mathrm{~A}$ more accurate picture shows that the ILO and the EU maintain a similar stance with respect to allocating formal roles to NGOs. Both institutions grant formal norm-generating power to their social partners, but they have yet to extend such authority to NGOs. The White Paper issued in 2001 included the Commission's momentous declaration regarding the signifcance it attributes to civil society's participation in EU governance; however, the full scope of such cooperation has yet to be formulated. Similarly, the ILO grants NGOs merely passive participation rights that do not include the right to attend sessions and to make statements. ${ }^{87}$ Unfortunately, the assertion that the EU's discourse with civil society in practice amounts to no more than a "thin frame for improving trans-

84. See id. II 382.

85. See Milman-Sivan, supra note 2, manuscript at 33-36 (contending that deliberative internal structure could bring about the inclusion of a broader array of interests, even beyond the narrow interests of the groups' constituents).

86. See Novitz \& Syrpis, supra note 3, at 394.

87. For a thorough discussion of the status of NGOs in the ILO, see Nolte \& Lagodinsky, supra note 66 , at 321 . 
national consultation process ${ }^{\text {'88 }}$ seems both accurate and noteworthy. This, for the most part, describes the ILO's approach as well. In fact, acknowledging the neocorporatist-like tendencies that characterize the social dialogue of the ILO and the $\mathrm{EU}^{89}$ better captures the current practice in both. In light of these common tendencies, the ILO experience has much to offer the EU.

As previously mentioned, an attempt to regulate the internal structures of functional groups in order to enhance representation poses an inherent danger, as it may enable interference in the regulatory independence of civil society groups. The ILO experience, however, sheds light on the implicit disadvantages of avoiding such regulation, as demonstrated by the damage to the legitimacy of both the $\mathrm{CC}$ and the ILO until the 2005 reforms.

Understanding the EU social dialogue in the more general context of its democratic deficit underscores the benefits gained by this in-depth approach to representativity. Moreover, in doing so, it frames the issue in terms of legitimizing losses and gains. From this perspective, the outcome and implications of the UEAPME case, which afforded the Commission a role that "clearly involved a very large degree of discretion" is particularly problematic. ${ }^{90}$

The ILO experience provides important insight on the avenues available to an international body striving to enhance the participation of private bodies without curbing its own legitimacy. Clearly, the ILO chose to adopt a broad understanding of representativity, while drawing on its own core norms (freedom of association). Indeed, the recent shifts at the ILO underline a particular aspect of freedom of association "as one of the procedural rights to discursive participation." "91

88. Kenneth A. Armstrong, Rediscovering Civil Society: The European Union and the White Paper on Governance, 8 EUR. L. J. 102, 121 (2002).

89. See Novitz \& Syrpis, supra note 3, at 382-92. I add "like" to emphasize the distinctions between the theory of neo-corporatism on the national and supernational level. For the applicability of the notion of neo-corporatism in the international sphere more generally, see Marina Ottaway, Corporatism Goes Global: International Organizations, Nongovernmental Organizations, Nongovernmental Organization Networks, and Transnational Business, 7 Global GovernanCE 265 (2001). Similarly one must also take into account the differences between the functions of the ILO tripartite structure, not purporting to establish dual "collective bargaining," and the EU social dialogue. This, of course, does not amount to a claim that either institution can be classified as perfectly falling within the realm of neo-corporatism on the national level. For the view that the EU social dialogue does not fall within the model of neo-corporatism, despite its tendency to be incorporated in the sphere of public relevance, see Lo FARO, supra note 14, at 124-32.

90. Adelina Adinolf, Admissibility of Action for Annulment by the Social Partners and "Sufficient Representativity" of European Agreements, 25 Eur. L. REv. 165, 176 (2000).

91. For a concise survey of the notion of freedom of association as a procedural social right, see Lo FARO, supra note 14, at 153, which draws on Habermas' theory of social rights. 
In light of the ILO experience, the EU should consider a full constitutional commitment to freedom of association. This may "give rise to a reinvigorated conception of the social dialogue as the principle informing a consensus-based administration of social and labour policies. ${ }^{\text {'p2 }}$ Such conceptualization of freedom of association will link the procedural aspect of freedom of association with democracy, as the former provides the ground rules for more democratic deliberation in the EU. It further underscores, as Antonio Lo Faro notes, "the duality of functions already emphasized by Otto Kahn-Freund: 'Freedom of organisation has the dual aspect of being an individual human right and a condition of social organization." ${ }^{3}$

Limiting the Commission's discretion by drawing on the norm of freedom of association could be just one positive consequence of such a development. In the absence of clear guidelines, the current discretionary latitude of the Commission is, and ought to be, a cause for concern. A full constitutionalization of freedom of association could elevate incorporating freedom of association as a criterion for representativity, which in turn could serve as a guideline for limiting both the discretion of the courts and the discretion of the Commission. The criterion of freedom of association could clarify when an intervention in the internal structure of the EU social partners may be legitimate.

As previously noted, freedom of association is a norm that balances the regulatory autonomy of social partners with the need to ensure adherence to particular, democratic, internal group mechanisms. Thus, the discretion of the Commission and the courts could be constrained by following the balance indicated in the jurisprudence of the norm of freedom of association.

The freedom of association norm could further illuminate the nature of appropriate or democratic internal structures. Obviously, the freedom of association norm cannot be immediately applicable to all situations, as is the case in the Bercusson examples noted above. For example, the EU social partners are structured as federations that incorporate groups from many nations, while freedom of association was developed to address concerns on a national level. ${ }^{94}$ In addition, lacking the relatively rich jurisprudence the ILO enjoys, the norm is not yet fully

92. Id. Lo Faro's recommendation to a comprehensive commitment by the EU to the norm of freedom of association is the end of a multi-faceted logic, which is beyond the scope of this work. For a detailed summary of this work, see id. at 155-61. Note, however, that in order to achieve this comprehensive role of the norm of freedom of association, it must be understood broadly, as including the right to bargain and the right to strike, similar to its interpretation in the ILO.

93. Id. at 154.

94. I am grateful to Ralf Rogowsky for raising this point at the Montreal Law and Society Conference in 2008. 
developed in the European arena. When such jurisprudence develops, the EU could be inspired by freedom of association doctrines, which regulate the relations between national and local organizations, for example. Other relevant analogies may be drawn from the national level practices of freedom of association. Although this approach may fall short of providing precise answers, it may nevertheless offer much needed guidance.

Further, to the extent that freedom of association offers an internal, comprehensible, and normative guideline, one that reflects the established normative preferences of the EU, it may further strengthen the legitimacy of the EU social dialogue. If the grounds for criticism of social dialogue were based on canons of liberal democracy, ${ }^{95}$ or on business definitions, ${ }^{96}$ freedom of association could provide a more legitimate point of departure for reviewing internal decision-making processes of corporatist groups.

Such an approach, of course, must consider the disparities between the ILO and the EU regarding the current status of the freedom of association norm. While freedom of association is considered a "meta-norm" in the ILO, ${ }^{97}$ the status of freedom of association in the EU is substantially different. The EU does not currently fully recognize the freedom of association as an EU constitutional norm in its described comprehensive scheme. It recognized the norm of freedom of association in its Charter of Fundamental Rights, ${ }^{98}$ (Charter), and thus granted it constitutional validity; ${ }^{99}$ however, the justiciable status of the rights enshrined therein remain unclear. Article 52(6) of the Charter explicitly stipulates that full account will be taken of national laws and practices. Furthermore, Novitz notes

95. See Obradovic, supra note 8 , at 368 .

96. See id. at 370.

97. Milman-Sivan, supra note 2, manuscript at 31-32.

98. Charter of Fundamental Rights of the European Union art. 12, 2007 O.J. (C 303) 1 [hereinafter Charter].

99. The right of freedom of association was already recognized in Article 11 of the European Convention on Human Rights and Fundamental Freedoms, signed in Rome in 1950. European Social Charter, art. 11, Nov. 4, 1950, ETS No. 5, available at http://www.pfc.org.uk/node/328. Later, it was mentioned as "The Right to Organize" in Article 5 of the European Social Charter from 1961. European Social Charter, art. 5, Oct. 18, 1961, ETS No. 35, available at http://conventions.coe.int/ treaty/en/treaties/html/035.htm. In the revised European Social Charter from 1996, the phrase "Freedom of Association" was inserted in the first chapter as a reference to Article 5. European Social Charter, art. 5, May 3, 1996, ETS No. 163, available at http:/conventions.coe.int/Treaty/EN/Treaties $/ \mathrm{Html} / 163$.htm. The signing of The Charter of Fundamental Rights in December 2000 signified new hope of unification. See Draft Charter of Fundamental Rights of the European Union If 2-3, Oct. 11, 2000, CHARTE 4473/00, available at http://www.europarleuropa.eu/charter/pdf/04473_ en.pdf, as full ratification will confer a binding effect to the unified charter. 
that while the members of the ILO identify and feel the need to act upon the organization's objectives, the European Court of Justice (ECJ) has been reluctant to apply its own principles and norms and has tended "to reflect and amplify member states' decisions." ${ }^{100}$ Accordingly, a full assessment of the status of freedom of association in the EU would require an analysis of the norm in the various member states. ${ }^{101}$ This requirement in itself, however, does not disqualify the argument for a future constitutionalization of freedom of association. The ECJ has already recognized the norm of freedom of association as key in the EU. The Charter has been incorporated in the Treaty of Lisbon, ${ }^{102}$ which, once ratified, will confer on the Charter a binding effect, enabling the full enforcement of its norms in the ECJ and in the European Court of Human Rights.

Finally, assigning a more significant role to the norm of freedom of association in conceptualizing the representativity debate is also consistent with Bercusson's conceptual framework of the EU social dialogue. Bercusson elucidates the two contrasting frameworks that may be used to understand EU social dialogue: the EU constitutional law model, which relies on participatory democracy, on the one hand, and the industrial relations model, embedded in a national labor law system, on the orher. Both conceptual frameworks are viable because the EU social dialogue, as enshrined in Articles 138-139 of the Treaty, incorporates elements from both models. Smismans articulates these different perspectives clearly. "The constitutional perspective sees the European social dialogue mainly as a regulatory technique, focusing on how such a procedure would fit with democratic standards. The labour law perspective, on the other hand, tends to stress the autonomous dimension of social dialogue as based in traditions of industrial relations." ${ }^{\text {"03 }}$ Bercusson advocates a mixed European labor law model, insisting that the constitutional model, adopted by the CFI, should not be exclusive. A deeper commitment to freedom of association, particularly with respect to representativity as discussed herein, may serve to further collapse the dichotomy between these two perspectives, as freedom of association is anchored in labor law, and, at the same time, incorporates constitutional values and implicit democratic principles.

100. Tonia Novitz, International and European Protection of the Right to Strike 263 (2003).

101. Note that the EU case law strongly suggests that the right of freedom of association does exist on the EU level. See, e.g., FranseEn, supra note 5, at 20.

102. Treaty of Lisbon Amending the Treaty on European Union and the Treaty Establishing the European Community, Dec. 13, 2007, 2007 O.J. (C 306) 1.

103. Smismans, supra note 14 , at 342. 


\section{Conclusion}

This article attempted to shed light on the representativity questions that arise from the formal insertion of private, functional groups within the EU social dialogue-a process that informs public, transnational norm generation in the EU. It points to the lessons that can be learned through the examination of another institutional context, in which similar questions have been raised and addressed: the ILO tripartite structure. While this article does not attempt to provide a full analysis of representativity in the EU and the ILO, it points toward the ILO as a particularly rich and uncharted terrain that can help advance this exploration in the EU.

Recent developments in the ILO, namely the CC reforms, seem to indicate that the ILO has increased its scrutiny of the internal functioning of worker and employer organizations that participate in its governance, through the insertion of freedom of association into the work of the CC. From the EU perspective, these developments highlight the complexity of representativity in civil society organizations, substantiating the claim that the notion of representativity should encompass the internal structural mechanisms of EU social partners. Identifying the representativity debate as an expression of the broader democratic question regarding the role of civil society in the EU further emphasizes the importance of maintaining a minimally democratic internal structure within groups that participate in EU norm generation. Finally, the ILO experience suggests that the norm of freedom of association could be of particular importance in conceptualizing the notion of representativity. I explored this idea in light of the constitutional status of freedom of association in the EU context and in light of the conceptual framework of the EU social dialogue. 


\title{
Indiana University Press/Journals
}

\author{
"A cheeky journal of culture and politics." - New York Times \\ "The only decent forum for black intellectuals." - Village Voice
}
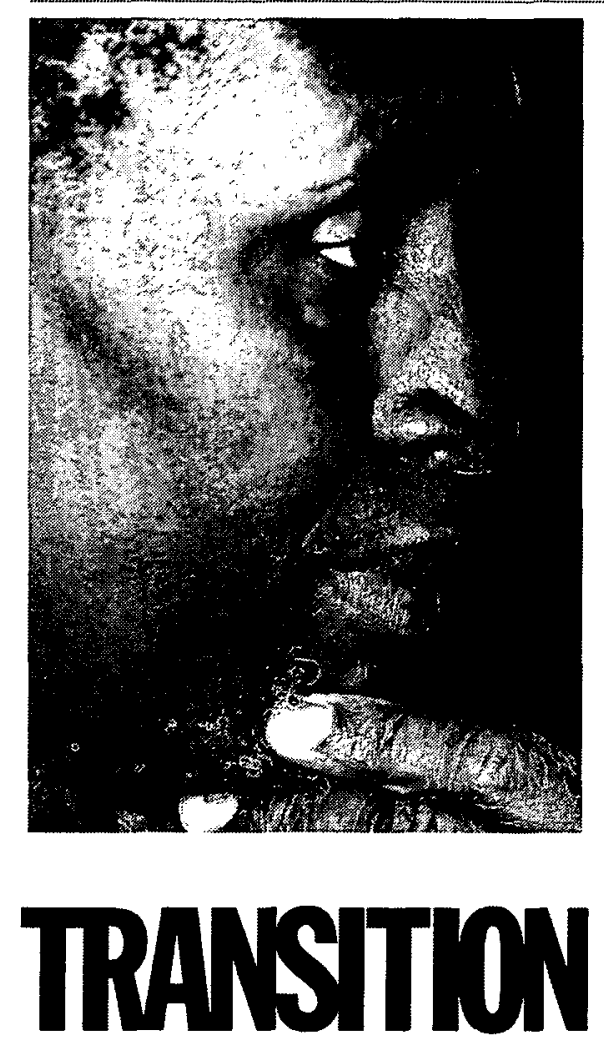

While other magazines routinely send journalists around the world, Transition invires the world to write back. Three times a year, its writers fill the magazine's pages with unusual dispatches, unforgettable memoirs, unorthodox polemics, unlikely conversations, and unsurpassed original fiction. A cosmopolitan journal with an emphasis on Africa and the diaspora, Transition tells complicated stories with elegant prose and beautiful images.

Contributors have included James Baldwin, Langston Hughes, Martin Luther King, Jr., Paul Theroux, Nadine Gordimer, Wole Soyinka, Jamaica Kincaid, Kofi Annan, Carlos Fuentes, Toni Morrison, Spike Lee, and Russell Banks. Essays from Transition have been reprinted in Best American Essays, The Beacon Best, Harpers, and the Utne Reader, while its fiction has been reprinted in Best American Short Stories and has been short-listed for the O'Henry Prize.

eISSN 1527-8042 pISSN 0041-1191

Transition is an international review of politics, culture, and ethnicity from Beijing to Bujumbura and is edited at the W.E.B. Du Bois Institute for African and African American Research at Harvard University.

800-842-6796/812-855-8817| http://inscribe.iupress.org Available in electronic, combined electronic \& print, and print formats

\section{II $\mid$\begin{tabular}{l} 
INDIANA UNIVERSITY PRESS \\
\hline INDIANA UNIVERSITY
\end{tabular}}

601 North Morton Street, Bloomington, Indiana 47404-3797 USA 